\title{
Comparing farmers' qualitative evaluation of soil fertility with quantitative soil fertility indicators in Kitui County, Kenya
}

Article

Accepted Version

Creative Commons: Attribution-Noncommercial-No Derivative Works 4.0

Yageta, Y., Osbahr, H., Morimoto, Y. and Clark, J. (2019)

Comparing farmers' qualitative evaluation of soil fertility with quantitative soil fertility indicators in Kitui County, Kenya. Geoderma, 344. pp. 153-163. ISSN 0016-7061 doi: https://doi.org/10.1016/j.geoderma.2019.01.019 Available at https://centaur.reading.ac.uk/81968/

It is advisable to refer to the publisher's version if you intend to cite from the work. See Guidance on citing.

To link to this article DOI: http://dx.doi.org/10.1016/j.geoderma.2019.01.019

Publisher: Elsevier

All outputs in CentAUR are protected by Intellectual Property Rights law, including copyright law. Copyright and IPR is retained by the creators or other copyright holders. Terms and conditions for use of this material are defined in the End User Agreement.

www.reading.ac.uk/centaur 
Central Archive at the University of Reading

Reading's research outputs online 
1 Title page

2

3 Geoderma Type of paper: Original research paper

4

5 Title: Comparing farmers' qualitative evaluation of soil fertility with quantitative soil fertility 6 indicators in Kitui County, Kenya

7

8 Yoshie Yageta $^{1}$, Henny Osbahr ${ }^{1}$, Yasuyuki Morimoto ${ }^{2}$, Joanna Clark ${ }^{3}$

91 School of Agriculture, Policy and Development, University of Reading

102 Kenya Country Office, Bioversity International, Kenya

113 Department of Geography and Environmental Science, University of Reading

12

13 Corresponding author: Yoshie Yageta

14 Email address: y.yageta@pgr.reading.ac.uk

15 Phone: +39339167 7591

16 Postal address: School of Agriculture, Policy and Development, University of Reading, Whiteknights, PO 17 Box 237, Reading RG6 6AR, UK 
Soil fertility is vital for agricultural productivity, yet poor soils and erosion remain a management challenge in many parts of sub-Saharan Africa. One challenge is that soil scientists and farmers often evaluate soil fertility using different knowledge systems and the implications have not been clearly reconciled within the literature. In particular, whether farmers are observing similar aspects of structure and function as classified in soil science. If so, what can we learn about how soil fertility is evaluated and communicated in terms of developing a hybrid approach that improves communication of ideas between different stakeholders. This paper addresses this challenge by examining the similarities and differences between farmers' qualitative evaluation and soil science quantitative analysis for soil fertility classification, and how location of soils influence farmers' evaluation of soil fertility. Empirical fieldwork was carried out in two villages in Kitui County, Kenya with 60 farmers using semi-structured interviews and focus group discussion. Based on farmer perception, 116 soil samples of the best and worst soil fertility taken and analysed for physiochemical factors. Farmers had a consistent classification system and primarily relied on texture and colour as indicators for good soil fertility and texture alone for poor soils. Soils with fine texture under the local semi-arid climate were associated with higher $\mathrm{pH}$, TOC and WHC and fertile black and red soils were associated with $\mathrm{pH}, \mathrm{TOC}$, WHC and AP based on differences in bed rock. Poor soil fertility was associated with sandy soils and soils with no colour in their local name. Spatial location is an important consideration in farmers' evaluations, reflecting awareness of local diversity in soil and historical social or environmental factors. Local historical narratives reveal the importance in changes to humus, consistent with technical knowledge about the role of soil organic matter for soil fertility. The paper provides better understanding of farmers' soil classification, evaluation processes and perspectives that help to inform scientists working with alternative frameworks for assessment and, in doing so, supports the development of local tailor-made soil assessment systems. 


\section{Introduction}

Soil is the basis of life for both human food security and the building of the natural environment. Soil fertility information is essential to improve soil productivity and identify suitable land management. While soil scientists have developed chemical, physical and biological methods to measure soil fertility (Jones, 1982), evaluation is not limited to scientific measures, but is also qualitatively understood by farmers (Roland, Rubens and Azupogo, 2018). Criticism of the limited effectiveness of implementing top-down technology and scientific transfer of information through extension services has led to increasing attention on the value and integration of local knowledge held by farmers (Barrios and Trejo, 2003; Berazneva et al., 2018; Guzman et al., 2018; Richelle et al., 2018). Fundamental presupposition of Eurocentric science are "nature is knowable" and Eurocentric scientists try to understand "the structure and function of the whole in terms of the structure and function of its parts"(Irzik 1998: 168). Indigenous knowledge is an empirical knowledge within local people accumulated with experiences, society-nature relationships, community practices and institutions, and by passing toward generations (Brokensha et al., 1980).

Farmers observe and evaluate their local soil experience for making everyday land management decisions (Rushemuka et al., 2014; Bado and Bationo, 2018). Integrating local knowledge helps match extension workers efforts with local needs, and may achieve improved adoption of co-produced technology (Ingram et al., 2018). Rocheleau (1988 cited in Walker et al. 1995) also point out that effective external interventions are best achieved 'once we know what they already know, and what else might be most useful to add to their store of knowledge and tools' (p236 in Walker et al. 1995). Farmers' evaluation of soil fertility is extensively reported as 'local' or 'farmers soil knowledge' in many ethnopedological studies (Barrera-Bassols and Zinck, 2003) and illustrates that farmers may understand aspects of function and scientific characteristics for their local soils but use different associations or framings to communicate and plan their land management.

Therefore, mutual understanding between farmers and scientists is not easy due to the ways that local knowledge systems contrast with scientific knowledge systems (Agrawal, 1995). Barrios et al. (2006) noted that while both systems share core concepts, such as the role of water for crop growth, each knowledge system has gaps and these are complemented by each other (Figure 1). They also argued that seeking a balance between scientific precision and local relevance expands shared knowledge to generate a new, hybrid knowledge system. Black (2000; p125-126) argued that "while many traditional problems may be solved with new methods, new problems, particularly environmental problems, may be best dealt with through a combination of new and traditional extension.”

The starting point of soil fertility evaluation by farmers and soil scientists are same: the performance of crop growth (Vilenskii, 1957; Murage et al., 2000). In addition, farmers also explain the characteristics of fertile or non-fertile soils, mainly by visual and morphological features, such as texture and colour which was used as universal criteria of soil fertility (Mairura et al. 2007 in Central Kenya; Kamidohzono et al. 
2002 in West Sumatra). Even from the same starting point, the direction of interests is different. Soil scientists measure soil as a natural resource using quantitative analysis, while farmers evaluate soils as part of their daily experience in the field (Ingram, Fry and Mathieu, 2010). Farmers have more 'know-how' or 'practical knowledge' about soil, and scientists have more scientific knowledge or 'know-why' about soil (Ingram, 2008). These differences can be categorized into three main parts: perception of other environmental information; spatial scale; and timescale.

The first difference is the extent to which additional environmental information is used to evaluate soil fertility. Farmers' evaluation of their soil is holistic (Barrera-Bassols and Zinck, 2003), where they see the soil resulting from a suite of interacting, complex environmental factors. For example, farmers often change their ranking of soil fertility based on seasonal rainfall (Osbahr and Allan, 2003). Moreover, from a geographical perspective, farmers perceive soil as the base for the environment, and thus local soil classifications incorporate land cover types (such as vegetation) (Duvall, 2008). By contrast, soil science reflects the reductionist approach used by natural science, which focuses on understanding "the structure and function of the whole in terms of the structure and function of its parts" (Irzik 1998: 168). Scientists often examine just one or two factors in isolation, for example in terms of their impact on crop performance. One scientific definition of soil fertility is "a soil that is fertile enough to provide adequate roots depth, nutrients, oxygen, water and a suitable temperature and no toxicities" (Wild 2003; 51). To explain the various factors, soil scientists focus on individual parameters and measure soil fertility predominantly by chemical and additional biological analysis or physical measurement in a laboratory and via direct measurement of environmental values (Landon 1984).

Second, farmers' evaluation focuses on a smaller scale, related to farm, field and within-field plots, reflecting subtle understandings of soil diversity. Many studies have shown that local soil classification is more detailed than international soil classification (Barrera-Bassols and Zinck, 2003; Osbahr and Allan, 2003). It may be argued that farmers are able to evaluate soils in suitable ways for their farm management and soil scientists are able to generalize sample data to explain underlying patterns across landscapes and make maps. Of course, detailed local knowledge has the limitation of site specificity (Cook, Adams and Corner, 1998) and scientific soil classification or mapping can provide insights at regional, national and global scales. While the main reason for soil classification or mapping is use for planning of soil conservation and soil management improvement to lead to better plant growth, original baseline data for the classification of soils were generated by soil survey, topographic and geological mapping which relates to pedology and a focus on soil formation (Brady \& Weil 1996). Originally, soil maps were designed to deliver information for managing landscapes and to create a common language of soils, with underlying general principles that explain complexity. Generalizations were necessary at landscape scale (Ashman and Puri, 2008) and thus the scale for farmer and science knowledge systems deviates.

The third difference is the timescale considered during evaluation. Farmers remember the history of their 
soils and how local knowledge has been shaped over a decades, including the influence of past management or specific events (that lead to improved soil or soil erosion for example) (Scott and Walter, 1993). By contrast, the timescale which soil scientists focus on differs; from the establishment of soil science, the pedological viewpoint is that soils form naturally over thousands of years (Yaalon and Berkowicz, 1997; Brady and Weil, 2016) but soil surveys for assessment focus on the immediate or current condition of the soil (often based on one-time sampling) (Landon, 1984).

The implications of these differences have not been clearly reconciled within the literature. In particular, whether farmers are observing similar aspects of structure and function as classified in soil science, and if so, what can we learn about how soil fertility is evaluated and communicated in terms of a hybrid approach. To address this challenge, this paper will: examine the similarities and differences between farmers' qualitative evaluation and soil science quantitative analysis for soil fertility classification; explore how the location of soils (e.g. villages and distance from home) influence farmers' evaluation of soil fertility. Location of soils includes the effect of social and environmental different and historical background of settlement. By examining these different approaches through a case study from Kenya, the paper will be able to highlight the potential value of improved awareness about local narratives of soil fertility, which reflect holistic knowledge systems and livelihood experience, and have implications for developing an integrated soil management approach.

\section{Approach and Method}

\section{The role of the case study approach}

The research approach adopted was to use an illustrative case study that enables capture of detailed local level understanding and to incorporate people (Yin, 2013), which may not be possible in a large scale soil study (Wilbanks and Kates, 1999). Kenya was selected because it is illustrative of a sub-Saharan developing country where agriculture dominates the national economy (Wambugu, Karugia and Oluoch-Kosura, 2011) with more than $70 \%$ of the population relying on small scale farming (Republic of Kenya, 2014).

Within Kenya, the research focused on Kitui County, located about $170 \mathrm{~km}$ east of Nairobi (Figure 2). The first rationale for selecting this county is the identification of contrasting soil types as recorded on the soil map for the region, resulting from the metamorphic bedrock and variation of slope (Mine \& Geological Department Kenya colony North-West Quadrant, 1954; Sombroek, Braun and Pouw, 1980). The area has a semi-arid climate, with temperature between $14^{\circ} \mathrm{C}$ to $34^{\circ} \mathrm{C}$, and two rainy seasons: 'long' from March to May and 'short' from October to December approximately (County Government of Kitui, 2014). The exact period and amount of rain is erratic and unpredictable from year to year, with annual rainfall between $250 \mathrm{~mm}$ and 1050mm (County Government of Kitui, 2013). The major ethno-cultural group is the 

The Kamba have practiced livestock rearing, hunting and farming for centuries, introducing rhizome and pulse cultivation from the $17^{\text {th }}$ Century (Ikeno 1989). The population living and farming on marginal lands have increased since the $20^{\text {th }}$ Century when many Kamba moved from neighbouring Machakos to move from poor soils with high rates of degradation (Ikeno, 1989; Karanja et al., 2017). Today, $87 \%$ of residents earn their livelihoods from agriculture using an average 2 ha farm, with additional income from salary, casual local labouring and migrant work (County Government of Kitui, 2013). Both mixed and monoculture rainfed farming is practiced with maize, legumes, green grams, cowpea and pigeon pea as the main crops. Small numbers of livestock are owned and the manure is used to fertilise the fields, although the amount is limited. The use of chemical fertilizer is low due to the cost (Ralph et al., 2006; County Government of Kitui, 2013). The second rationale for selection was the deep cultural rural farming knowledge and that a traditional land use system is practised, similar to other parts of Kenya. This land use system includes three types of enterprise areas: out-fields (away field), in-fields (home garden) and a home site (kitchen gardens) (Woomer et al., 1998).

Within Kitui County, two villages were selected using purposive sampling (Tongco, 2007) to evaluate the effect of the difference of location for soil knowledge. Four criteria were used: (a) location in the same soil type based on the national soil map and in same Agro-Ecological Zone (AEZ); (b) a majority of villagers as smallscale farmers; (c) no active NGO activity or agricultural extension projects; (d) different distances from Kitui town centre and different frequency of communication with extension workers (one higher than the other). Soil types indicate soil general properties so they are assumed to affect farmers' perception of soils and fertility, and AEZ represents the climate condition of the area. Therefore, it was important to take data from the same high-level soil type and AEZ to reduce excessive variation of natural factors and focus on variation from social and management factors. The distance from town centre can affect the level of extension service, and therefore, access to scientific knowledge (Anderson, 2006). A national soil map, AEZ map (Sombroek, Braun and Pouw, 1980), and road map (WFP, 2007) of Kenya were processed on ArcGIS to identify the potential area and then shown on Google Earth. The national soil map (Sombroek, Braun and Pouw, 1980) identifies the study area as Um19; 'well drained, moderately deep to deep, dark reddish brown to dark yellowish brown, friable to firm, sandy clay to clay; in many place with top soils of loamy sand to sandy loam (ferralo-chromic/ orthic/ ferric ACRISOLS; with LUVISOLS and FERRALSOLS)' (p25). Acrisols and Luvisols are determined by the existence of Argic horizon (accumulation of clay) and classified by CEC (less than $24 \mathrm{cmol}_{\mathrm{c}} \mathrm{kg}^{-1}$ is for Acrisols and more than 24 $\mathrm{cmol}_{\mathrm{c}} \mathrm{kg}^{-1}$ is for Luvisols) and base saturation (less than $50 \%$ for both) (IUSS Working Group WRB, 2015). Ferralsols are determined by a red colour and low activity clay minerals (IUSS Working Group WRB, 2015). The national soil map does not describe a finer level of soil differentiation. The bedrock is marked as area $\mathrm{Xg}$ on the Geological map for Kitui (Mine \& Geological Department Kenya colony North-West 
anplibolite schlieren granitic sheet and vien reticulation'.

198 Visits to villages to triangulate the soil data was conducted and, with support from Agricultural Extension,

199 Village1 (Kavuti) and Village2 (Kitambasyee) were selected to represent locations with similar 200 environmental conditions but different social conditions (Figure 3). GPS data showed elevation was similar 201 (1180m in Village1 and 1000m in Village2) and field slope were similar with flat to moderately steep (0 to 202 25\%) (Soil Survey Division Staff, 2017). Village1 was located near Kitui town (4.5 km) with historically 203 frequent communication from Agricultural Extension officials - the village was located near the chief's 204 office and where public meetings are held, a Ministry of Agriculture official lived in the village, and some 205 farmers had relatives or friends who engaged with volunteer extension activities. Village2 was located $20620 \mathrm{~km}$ from the town, although due to limited transport it can take more than two hours to walk), and there was limited communication with Agricultural Extension officials.

\section{Data collection: Farmer knowledge}

210 Data was collected between January and October 2017. To understand the relationship between farmers' 211 knowledge of soil fertility and soil physicochemical parameters, a mixed method approach was used 212 (Robson, 2011). Information about farmers' evaluation of soil fertility was collected using individual 213 interviews and a semi-structured guide to collect both qualitative and quantitative data (Robson, 2011).The 214 questionnaire for interview was constructed with the questions to collect the data about the indicators of 215 soil fertility, the location and scale of the best and the worst soil in farmers' fields. Although farmers are managers of different farms and recognize small difference even in the same field, this research focused on soils that farmers evaluated as the best or worst fertility location to avoid over-complexity. Approximately $50 \%$ of the total number of households in each village was randomly sampled and the person who decides management of their fields (usually the household head or wife) was selected as interviewees purposively inside each household. The total number of sampled farmers was 60 (30 in each village). Focus group discussions supplemented understanding of the historical narratives. Purposive sampling (Tongco, 2007) for participants was used as elder farmers (four farmers per a village, range of age is between 53 and 83 years old, who know historical change of soil and agriculture) were able to discuss the historical context. The questions for group discussion included previous soil condition and farmers' lifestyle, and social and environmental change affected on the change of soil fertility. A trained local translator was used for discussion between English and KiKamba, although some farmers spoke English. All data was recorded with permission.

\section{Soil sampling and laboratory analysis}

230 Soil samples were collected in August 2017 from the best and the worst fertile place in fields, as identified by each farmer. The sampling occurred just after harvest and the last short rains in fields that had not yet been prepared for next growing season. This was considered good timing for evaluating baseline soil nutrient status with minimal impact from additional inputs. Surface $(10 \mathrm{~cm})$ soil samples were taken from 
10 points within each field and bulked to make single composite samples of 500g. The total number of soil samples was 116, 59 from the best fertile locations and 57 from the worst fertile places. This was because four farmers had just one farm and one of them evaluated their field as not fertile only while another evaluated their fields as fertile only.

A sub-sample was sieved to $0.5 \mathrm{~mm}$ for available phosphorus analysis. The remaining soils were sieved to $2 \mathrm{~mm}$ for further analysis, stored to air dry at ambient temperature for use in other physical and chemical analysis. Nitrate-Nitrogen was measured within one week after sampling by extraction in $2.0 \mathrm{M}$ potassium chloride $(\mathrm{KCl})$.

For soil physical measurements, colour of soils (wet and dry) was determined using a Munsell colour chart and texture using the ball and ribbon method (Thien, 1979). Water Holding Capacity (WHC) was measured by simplified method from soil laboratory in University of Reading. This process requires approximately $50 \mathrm{~g}$ of air-dry soil to be placed into a plastic container and then into a dish of water for 6 hours to allow saturation. Afterwards, containers were removed and covered to prevent evaporation, suspended on a retort stand to allow drainage and dried overnight. Approximately half of the wet soil from each container was removed and pre-weighed in an aluminium dish. Then a) the mass of the dish and b) the mass of the wet soil and dish were recorded and dishes put in an oven at $105^{\circ} \mathrm{C}$ for 24 hours. Dishes were placed in a desiccator to cool and then weighed with mass recorded. The water holding capacity could be calculated as: WHC $(\%)=($ mass of drained soil - mass of oven dried soil)/ mass of oven dried soil x 100 .

For the chemical parameters, $\mathrm{pH}$ in $\mathrm{H}_{2} \mathrm{O}(1: 2.5)$ was measured using a glass electrode $\mathrm{pH}$ meter (Carter and Gregorich. 2008) and electronical conductivity $\left(\mathrm{EC}_{1: 1}\right)$ was measured using a conductivity meter (Richards, 1954). The Total Organic Carbon (TOC) was determined by the Walkley-Black method (Walkley 1947), Kjedhal Method (Okalebo et al. 1993) was used for Total-Nitrogen (T-N), and Nitrate-Nitrogen $(\mathrm{N}-\mathrm{N})$ was extracted with $2.0 \mathrm{M} \mathrm{KCL}$ and measured by $0.01 \mathrm{~N} \mathrm{H} 2 \mathrm{SO} 4$ using an Auto-Titrator (Keeney and Nelson, 1982). Available Phosphorus (P) was measured by Mehlich 1 (Mehlich, 1953; Nelson, Mehlich and Winters, 1953), Exchangeable Potassium (K) and Sodium (Na) were extracted by ammonium acetate and measured using an atomic absorption spectrophotometer and Cation Exchange Capacity (CEC) was assessed with ammonium acetate after exchangeable cation extraction using the semi-micro distillation method (Lavkulich, 1981).

All data collection in Kenya was done under a research permit from National Commission for Science, Technology \& Innovation (NACOSTI). All data from interview and focus group were received under 
of soil names, soil characteristics, location and scale of the best and worst soil in farmers' fields. Additionally, simple descriptive statistics were used. Narratives from the interviews and focus groups were organised to reveal insight to these identified patterns. Results from the soil physicochemical analysis were compared to farmers' evaluations to understand patterns and relationships and between the villages. Statistical analysis of quantitative data was performed using Minitab 17. Pearson chi-squared test was used to assess differences between 1) villages and farmer-selected location of the best and worst fertility soil, 2) farmers' soil fertility evaluation and local soil name, 3) villages and soil texture and 4) villages and locally determined soil colour classifications. A General Linear Model (GLM) was used to explore difference between the physicochemical data and farmers' evaluations of soil fertility. A multiple comparison approach was used to compare relationships between soil physiochemical data and soil texture/locally determined colour classifications. The results of TOC, TN, NN, AP, K, Na, CEC and EC took the Log of the data first and then fitted the GLM to the logged data to consider normality of residuals.

\section{Results}

Results from local soil knowledge analysis are presented first, including characteristics used by farmers to evaluate the best and the worst soil fertility, use of scale and location and farmers' terminology. Soil physicochemical parameters are then introduced and compared with farmers' evaluations of best and worst fertility to identify similarities and/or differences.

Farmer knowledge: Key soil properties used in farmers' evaluation of soil fertility The characteristics of soils of the best and worst fertile places were described by farmer in response to an open question (Figure 4). Texture was the primary soil property used by farmers to evaluate both best and worst fertility. Colour was used to identify best fertility. There were other properties used by farmers, but these were less commonly used across the whole group. In total, 13 soil properties were identified as indicators for both best and worst soil fertility: texture, colour, workability, plant performance, water, stoniness, weed, feeling, fertilizer, location, root and sub-soil. Temperature was used only as an indicator for worst soil fertility.

When describing best soil fertility ( $\mathrm{n}=59$, Figure $4-\mathrm{a}$ ), farmers relied on fine soil texture (80\%) and a black or red colour (55\%) to describe the soil. Of the farmers, $27 \%$ recognized a difference in soil workability (e.g. the need for only moderate wetness to plough easily whereas with very wet conditions soils can be difficult), $22 \%$ referred to good plant performance and linked this to water availability (12\%, "Even in dry season, I felt moisture when I dig the place" V2-6). Other facts mentioned included no stones (13\%), a 'good feeling' for soils (8\%), more 'fine' weeds (5\%, "It is easy to pull weeds out by hand" V1-5), past use of fertilizer (5\%, "I added a lot of manure in the place in the past, so now here is fertile" V1-4), location near house where there are often more inputs (5\%), longer roots of plants (2\%), and an observed different 
main factor (80\%) but considered as course texture. A light soil colour (20\%) was the second factor but reflect a smaller response in comparison to texture. Other indicators mentioned included difficult 'workability' of the soil (20\%, "The soil is too hard when it is dry so I need rain for plough." V1-16) less water availability (18\%, "The soil is dry faster due to drain faster" V1-29) and poor crop performance $(15 \%)$, more stones $(13 \%)$, no fertilizer use $(12 \%)$, many weeds $(5 \%)$, far from the house $(3 \%)$, a different type of sub-soils (3\%, "When dig the soil deeper, I found the red soil with shiny particles" V2-6), hotness (3\%, "When I dig the soil in dry season for preparation, the sandy soil is too hot" V2-15), small roots (2\%) and a 'bad feeling' (2\%).

Farmer knowledge: Role of farm scale and location

The scale of evaluation of soil fertility was very detailed within each farm. Farmers clearly understood differences in soil fertility. Out of the 60 interviewees, $88 \%$ were able to designate portions of their farm as the best or worst soil fertile place ("The portion near tree is better than other because of supply of leaves." V1-26, "My home field is located on slope so the bottom of slope is more fertile than up due to washed soil from up accumulate there." V2-13, "There is a portion of natural black soil in the centre of my field and there is more fertile." V2-22) while $12 \%$ evaluated their whole farm as having the same soil fertility ("The soil is same because my current field is quite small after dividing other for my children." V1-24).

Of the total sample, $46 \%$ selected the area around their house and inside the home-field as the primary location for best soil fertility. This kitchen garden or Mũthĩo (in Kikamba phonetic transcription, Whiteley $\&$ Muli 1962)is where livestock is often confined so manure and composts accumulate (Woomer et al., 1998). The next best soil fertility area identified by the total sample was near to a river (20\%). When comparing between the two villages, there are differences in response. Village1 reported that areas within their kitchen gardens were better (67\%) than their away-fields (20\%). In Village2, farmers evaluated their away-fields to have better soil fertility than kitchen gardens (24\%) (the difference between villages is significant, Pearson chi-squared test $\left.\mathrm{P}=0.006^{* *}\right)$. The influence of the river was important to soil fertility in Village2 (38\%). There were also differences in the number of fields managed by farmers between the villages; Householders with more than two fields being managed was $33 \%$ in Village1 and $77 \%$ in Village2. This difference affected their selection of the best soil fertility locations on their farm overall with farmers in Village 2 had more opportunity to use the good soils near the river.

Farmer knowledge: Local terminology for soil fertility evaluation

342 Farmers considered the fertility of soils through the healthiness of the crops grown. This connection was reflected in the articulation of soil fertility, with healthy (fertile) and non-healthy (unfertile) terminology used. Farmers perceived a connection between the healthiness of soils, plants and people (e.g. between good soils and production, food security and nutrition), and articulated this relationship using visual terms or outcomes (e.g. 'an overweight person would have fertile soil and more to eat'). In KiKamba, soil is called Mũthanga and the word for fertile is Mũnou so good fertility soil is described as Mũthanga Mũnou. 
The word Mũmosu is used to describe a lack of fertility, and therefore poor soil fertility is Mũthanga Mũmosu. Interestingly, Mũnou and Mũmosu were also terms used for expressing human healthiness. A

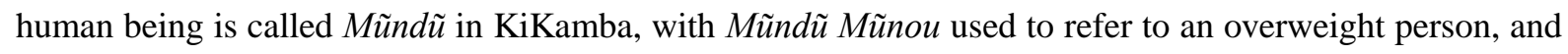
often used to convey being healthy or having contentment. In contrast, Mũndũ Mũmosu is used to refer to an unhealthy thinness or something lacking in the human body. Technical or science-based crop performance indicators were not used by farmers as the first terminology to describe soil fertility (Figure 4) as farmers considered it necessary to reflect initially on the characteristics of Mũthanga Mũnou (or Mũmosu) and the collective healthiness of the soil and the crops.

Table 1 presents farmers' soil classification terms and how these relate to their designations of best and worst soil fertility on their farms. Farmers relied on 11 classifications, eight locally-defined terms and three defined in the English language. The eight locally-defined terms were divided into three groups: feature of soil; fertility classification; and formation type. There were five categories based on physical soil properties, including texture and colour, sandy soil (locally known as Nthangathĩ), black soil (Mwiũ ), red soil (Mũtune), stony soil (Kĩvuthĩ) and black-clay soil found near rivers (Ĩlimba). Most answers were organised into these physical soil categories (91\%) and KiKamba terminology was used for the majority of soil classification labels by farmers in Kitui. Although there were some synonyms and a few instances of mixes of category, it was still possible to consistently identify a dominant soil type with farmers. For example, in the category of Mũtune (red soil), there were two synonyms Kĩtune and Ũtune and a mix with İlimba i.e. red soil with some black clay). Terminology for soil fertility can also be referred to as good (Mũnou) or bad (Yalata). There was just one category that reflected soil formation characteristics, which was a type of sedimentary soil called Kĩvumbu (other meaning of Kĩvumbu is clay soil found in termite mounds, personal communication with a local scientist). In addition to these local terms, three English terms were used to describe loam, clay and white soil.

There was a clear relationship between the terminology in farmers' soil classification and their evaluation of soil fertility (Table 1). Of the total, Mũnou (1 in 1), Kĩvumbu (1 in 1), Ĩlimba (12 in 12), Mwiũ (23 in 24), and Mũtune (13 in 19) were categories used to evaluate fertile soil. In contrast, course soil texture Nthangathĩ (29 in 34), Kivuthĩ (16 in 16) and Yalata (4 in 4) were used to evaluate poor fertility soils. The difference of local soil classification on farmers' fertility evaluation is significant (Pearson chi-squared test $\mathrm{P}=0.000^{* * *}$, with local soils including more than 10 soil samples used in the test), indicating that farmers were consistent in their use of local soil terminology and association of these terms with best and worst soils. In addition, there was a difference in occurrence of locally perceived soil types between the two study villages. Mwiũ and Mũtune (11 and 11 in 30) were dominant in Village1 and Mwiũ and Ĩlimba (12 and 11 in 29) were dominant in Village2 to describe good soil fertility. Nthangathĩ was dominant as the worst soil fertility in both villages, although Kĩvuthĩ was additionally recognized in Village2 as a worst soil fertility location. Notably, English terminology was only used in Village1. 
Texture associated with each local soil classification was compared to scientific analysis of soil samples. The results of texture analysis made by a hand test were aggregated into three categories: clayey refers to clay dominated ( $>35 \%$ clay), including clay, sandy clay and clay loam; loamy describes moderately sandy, including sandy clay loam and sandy loam; and sandy, which is sand dominated (>75\% sand), including loamy sand and sand. Clayey to loamy texture soil types were mainly classified from the best soil fertility locations, while course texture (sandy or stony) soils were classified from the worst soil fertility locations. Kivuchi and Yalata were classified as clayey to loamy texture using a hand test and those with significant stone content removed by sieving were classified as stony or course texture soils.

Soil samples were compared to a Munsell colour chart and named using the guide at https://logiteasy.com/free-tools/munsell-calculator.php. Soil colour was not significantly different across the soil classification by the chart. In total 11 soil colours were recognized but these were dominated by just three colour names (dark brown, dark yellowish brown and brown). Îlimba (6 in 12), Mwiũ (14 in 24), Nthangathĩ (16 in 34) and Kĩvuthĩ (7 in 16) were classified in dark brown, while Mũtune related to brown. The limited difference between soil colour name and local soil classification can be attributed to the naming system of the Munsell colour chart. The colour range to categorise dark brown, dark yellowish brown, brown and strong brown is wider than for other colours.

Table 1. Local soil classifications, with associated soil fertility and texture terminology (Source: Individual Interviews $\mathrm{N}=116$ sites, 30 farmers)

\begin{tabular}{|c|c|c|c|c|c|c|c|}
\hline \multirow{2}{*}{ Local soil name } & \multirow{2}{*}{$\begin{array}{l}\text { Meaning in } \\
\text { English }\end{array}$} & \multirow{2}{*}{$\begin{array}{c}\text { No of } \\
\text { samples }\end{array}$} & \multicolumn{2}{|c|}{ Fertility evaluation } & \multicolumn{3}{|c|}{ Texture } \\
\hline & & & Best & Worst & Clayey & Loamy & Sandy \\
\hline Мũnou & Good soil & 1 & 1 & 0 & 1 & 0 & 0 \\
\hline Kĩvumbu & $\begin{array}{l}\text { Sedimentary } \\
\text { soil }\end{array}$ & 1 & 1 & 0 & 1 & 0 & 0 \\
\hline Ĩlimba (Ĩlivĩ) & $\begin{array}{c}\text { Black clay soil } \\
\text { near river }\end{array}$ & 12 & 12 & 0 & 6 & 6 & 0 \\
\hline $\begin{array}{l}\text { Mwiũ } \quad(+ \text { Mũtune, } \\
+ \text { Nthangathĩ })\end{array}$ & Black Soil & 24 & 23 & 1 & 4 & 18 & 2 \\
\hline 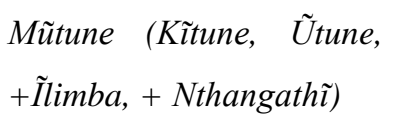 & Red Soil & 19 & 13 & 6 & 13 & 5 & 1 \\
\hline Loam soil & - & 2 & 2 & 0 & 1 & 1 & 0 \\
\hline Clay loam soil & - & 1 & 1 & 0 & 1 & 0 & 0 \\
\hline No name & - & 1 & 1 & 0 & 1 & 0 & 0 \\
\hline $\begin{array}{l}\text { Nthangathĩ } \quad(+ \text { Mwiũ, } \\
+ \text { Mũtune })\end{array}$ & Sandy Soil & 34 & 5 & 29 & 4 & 12 & 18 \\
\hline
\end{tabular}




\begin{tabular}{|c|c|c|c|c|c|c|c|}
\hline $\begin{array}{l}\text { Kĩvuthĩ } \quad \text { (Kithathai, } \\
\text { Uthathai, } \\
+ \text { Nthangathĩ) }\end{array}$ & Stony Soil & 16 & 0 & 16 & 8 & 5 & 3 \\
\hline $\begin{array}{l}\text { Yalata (Mwalata, Mwalata } \\
\text { Mwiũ) }\end{array}$ & Bad Soil & 4 & 0 & 4 & 2 & 2 & 0 \\
\hline White soil & - & 1 & 0 & 1 & 0 & 0 & 1 \\
\hline Total & & 116 & 59 & 57 & 42 & 49 & 25 \\
\hline
\end{tabular}

407

408 
409 Table 2. Soil colour by local soil classification organised by the Munsell colour chart (wet conditions)

410

\begin{tabular}{|c|c|c|c|c|c|c|c|c|c|c|c|c|}
\hline \multirow{3}{*}{ Local Soil Name } & \multicolumn{11}{|c|}{ Munsell Colour } & \multirow{3}{*}{ Total } \\
\hline & black & $\begin{array}{c}\text { very dark } \\
\text { brown }\end{array}$ & $\begin{array}{c}\text { very dark } \\
\text { grayish } \\
\text { brown }\end{array}$ & $\begin{array}{c}\text { dark } \\
\text { grayish } \\
\text { brown }\end{array}$ & $\begin{array}{l}\text { Dark } \\
\text { brown }\end{array}$ & $\begin{array}{c}\text { dark } \\
\text { yellowish } \\
\text { brown }\end{array}$ & brown & $\begin{array}{l}\text { strong } \\
\text { brown }\end{array}$ & $\begin{array}{c}\text { very } \\
\text { pale } \\
\text { brown }\end{array}$ & $\begin{array}{l}\text { reddish } \\
\text { brown }\end{array}$ & $\begin{array}{l}\text { yellowish } \\
\text { red }\end{array}$ & \\
\hline & 10YR1.7/1 & $\begin{array}{l}7.5 Y R 2 / 2, \\
2 / 3, \\
10 Y R 2 / 3\end{array}$ & 10YR3/2 & 10YR4/2 & $\begin{array}{c}7.5 Y R 3 / 3 \\
3 / 4 \\
10 Y R 3 / 3\end{array}$ & $\begin{array}{l}10 Y R 3 / 4, \\
4 / 4,4 / 6\end{array}$ & $\begin{array}{c}7.5 Y R 4 / 3, \\
4 / 4,5 / 4 \\
10 Y R 4 / 3, \\
5 / 3\end{array}$ & $\begin{array}{l}7.5 Y R 4 / 6 \\
5 / 6,6 / 6\end{array}$ & $10 Y R 7 / 4$ & $5 Y R 4 / 4$ & $5 Y R 5 / 6$ & \\
\hline Mũnou & & & & & & & & 1 & & & & 1 \\
\hline Kĩvumbu & & & & & & & 1 & & & & & 1 \\
\hline$\tilde{I} l i m b a(\tilde{I} l i v \tilde{\imath})$ & 1 & 3 & 2 & & 6 & & & & & & & 12 \\
\hline Mwiũ (+Mütune +Nthangathĩ) & & 1 & & 1 & 14 & 2 & 5 & 1 & & & & 24 \\
\hline $\begin{array}{l}\text { Mũtune (Kĩtune, Ũtune, +Ĩlimba, } \\
+ \text { Nthangathĩ) }\end{array}$ & & & & & 3 & 2 & 11 & 2 & & 1 & & 19 \\
\hline No name & & & & & & & 1 & & & & & 1 \\
\hline Clay loam soil & & & & & 1 & & & & & & & 1 \\
\hline Loam soil & & & & & 2 & & & & & & & 2 \\
\hline Nthangathĩ (+Mwiũ +Mũtune) & & & & & 16 & 13 & 5 & & & & & 34 \\
\hline $\begin{array}{l}\text { Kĩvuthĩ (Kĩthathai, } \quad \text { Uthathai, } \\
+ \text { Mũtune +Nthangathĩ) }\end{array}$ & & & & & 7 & 2 & 4 & 2 & & & 1 & 16 \\
\hline Yalata (Mwalata, Mwalata Mwiũ) & & & & & 2 & 1 & 1 & & & & & 4 \\
\hline White soil & & & & & & & & & 1 & & & 1 \\
\hline
\end{tabular}


Total \begin{tabular}{lllll}
\hline 4 & 2 & 1 & 51 & 20
\end{tabular}

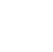

1

1 
Table 3. Physicochemical parameters of each local soil classification

\begin{tabular}{|c|c|c|c|c|c|c|c|c|c|c|}
\hline Local soil name & $\mathbf{p H}$ & $\begin{array}{l}\text { TOC } \\
\mathbf{g ~ k g}^{-1}\end{array}$ & $\begin{array}{c}\text { TN } \\
\mathbf{g} \\
\mathbf{k g}^{-1}\end{array}$ & $\begin{array}{l}\text { NN } \\
\text { mg } \\
\mathbf{k g}^{-1}\end{array}$ & $\begin{array}{c}\text { AP } \\
\text { mg } \\
\mathbf{k g}^{-1}\end{array}$ & $\begin{array}{c}\mathrm{K} \\
\mathbf{c m o l} \\
\mathbf{k g}^{-1}\end{array}$ & $\begin{array}{c}\mathrm{Na} \\
\mathrm{cmol} \\
\mathrm{kg}^{-1}\end{array}$ & $\begin{array}{c}\text { CEC } \\
\text { cmol } \\
\mathrm{kg}^{-1}\end{array}$ & $\begin{array}{c}\text { EC } \\
\text { ds/m }\end{array}$ & $\begin{array}{c}\text { WHC } \\
\%\end{array}$ \\
\hline \multicolumn{11}{|l|}{ Best Fertility } \\
\hline Mũnou & 6.7 & 21.0 & 2.1 & 12.5 & 56 & 0.92 & 0.20 & 7.9 & 0.04 & 61.2 \\
\hline Kĩvumbu & 7.4 & 10.1 & 3.4 & 19.3 & 114 & 0.42 & 0.23 & 14.1 & 0.05 & 55.7 \\
\hline$\tilde{I l i m b a}(\tilde{I} l i v \tilde{\imath})$ & 6.4 & 10.5 & 1.2 & 12.2 & 87 & 1.39 & 0.37 & 11.1 & 0.12 & 48.2 \\
\hline Mwiũ (+Mütune, +Nthangathĩ) & 6.7 & 10.6 & 1.1 & 11.6 & 109 & 1.16 & 0.43 & 10.3 & 0.09 & 42.0 \\
\hline $\begin{array}{l}\text { Mũtune (Kĩtune, Ũtune, +Ĩlimba, } \\
+ \text { Nthangagi) }\end{array}$ & 6.6 & 11.9 & 1.2 & 11.7 & 71 & 1.09 & 0.33 & 10.1 & 0.07 & 47.8 \\
\hline Loam soil & 6.6 & 12.4 & 1.0 & 10.1 & 86 & 1.29 & 0.27 & 11.3 & 0.05 & 49.3 \\
\hline Clay loam soil & 6.2 & 18.0 & 1.4 & 10.7 & 46 & 0.80 & 0.32 & 7.4 & 0.11 & 50.8 \\
\hline No name & 6.5 & 19.5 & 2.5 & 17.7 & 21 & 0.76 & 0.19 & 10.8 & 0.05 & 57.5 \\
\hline \multicolumn{11}{|l|}{ Worst fertility } \\
\hline Nthangathĩ $(+$ Mwiũ + Mũtune $)$ & 6.1 & 10.0 & 1.0 & 11.3 & 49 & 0.92 & 0.32 & 9.4 & 0.07 & 35.5 \\
\hline $\begin{array}{l}\text { Kĩvuthĩ (Kĩthathai, Ũthathai, } \\
+ \text { Mũtune, +Nthangathĩ) }\end{array}$ & 6.1 & 9.2 & 1.2 & 11.9 & 65 & 1.39 & 0.38 & 10.7 & 0.06 & 42.8 \\
\hline Yalata (Mwalata, Mwalata Mwiũ) & 6.2 & 10.8 & 1.1 & 11.3 & 84 & 1.49 & 0.30 & 9.5 & 0.10 & 44.6 \\
\hline White soil & 6.1 & 6.6 & 0.5 & 9.5 & 18 & 0.64 & 0.26 & 10.6 & 0.12 & 45.4 \\
\hline \multicolumn{11}{|l|}{ Summary information } \\
\hline Average (Best Fertility) & 6.6 & 11.5 & 1.2 & 11.9 & 87.4 & 1.2 & 0.4 & 10.4 & 0.09 & 45.3 \\
\hline Average (Worst Fertility) & 6.1 & 9.7 & 1.1 & 11.6 & 58.0 & 1.1 & 0.3 & 9.8 & 0.07 & 39.7 \\
\hline Average (All Samples) & 6.4 & 10.6 & 1.2 & 11.7 & 73 & 1.1 & 0.4 & 10.1 & 0.08 & 42.5 \\
\hline Critical level & $\geqq 5.5$ & $\geqq 27$ & $\geqq 2$ & n.d & $\geqq 30$ & $\geqq 0.24$ & n.d & n.d & n.d & n.d \\
\hline
\end{tabular}

414 Results of the physicochemical analysis were also different between local soil types, which were classified

415 into the best and worst soil fertility locations. When the physicochemical analysis was compared with

416 critical levels for maize production (NAAIAP 2014), average values of $\mathrm{pH}$, AP and $\mathrm{K}$ for all samples were

417 higher and Mũnou and Kĩvumbu show higher TN. However, for other soils TOC and TN are deficient. This

418 critical level indicates general deficiency of organic matter and sufficient mineral supply by bedrocks,

419 which are locally categorized as metamorphic rocks (Mine \& Geological Department Kenya Colony 1954).

420 Therefore, it can be implied low organic matter in the soil. 
The physicochemical analysis data was also statistically compared with the best and worst fertility soils. Using GLM analysis, soils from the best soil fertility locations were shown to have significantly higher average values than the worst soil fertility locations for $\mathrm{pH}$ ( 6.6 at the best/6.1 at the worst, $\left.\mathrm{P}=0.000^{* * *}\right)$, TOC (11. 5 and 9.7 $\left.\mathrm{g} \mathrm{kg}^{-1}, \mathrm{P}=0.003 * *\right)$, AP (87.4 and 58.0mg kg-1, $\left.\mathrm{P}=0.000 * * *\right), \mathrm{K}$ (1.2 and $1.1 \mathrm{cmol} \mathrm{kg}^{-1}$, $\mathrm{P}=0.032 *)$ and WFC (45.3 and 39.6\%, $\mathrm{P}=0.000 * * *)$. However, while TN (1.2 and $\left.1.1 \mathrm{~g} \mathrm{~kg}^{-1}, \mathrm{P}=0.088\right)$, NN

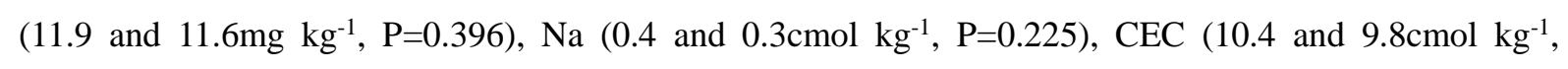
$\mathrm{P}=0.198)$ and $\mathrm{EC}(0.09$ and $0.07 \mathrm{ds} / \mathrm{m}, \mathrm{P}=0.088)$ in the best fertility soils showed higher values than the worst fertility soils these results are not significantly different. The factors from location were additionally included in the GLM analysis. The difference of villages was found to be significant for $\mathrm{pH}, \mathrm{TOC}, \mathrm{AP}, \mathrm{K}$, $\mathrm{Na}, \mathrm{CEC}, \mathrm{EC}$ and WHC. The difference of field location (home- or away-field) particularly affected the value of WHC, with away-fields having higher WHC than home-fields.

\section{Relationships between farmer' evaluation of soil fertility and soil physicochemical parameters}

Further analysis was carried out to examine the relationship between farmers' local knowledge and technical knowledge obtained through the above physicochemical analysis with respect to the two key soil properties farmers use to assess fertility: texture and colour (Figure 4).

The difference in soil texture can be shown to be reflected in the values found in the physicochemical analysis (Table 4-a). First, frequency of appearance of the three texture classes used for best and worst fertility places is significantly different. For example, for the whole sample, the best fertility soil has a finer texture than the worst fertility soil $(\mathrm{P}=0.002 * *)$. The village location further affected the soil texture, with significantly more clayey soils in Village1 than Village2 $\left(\mathrm{P}=0.015^{*}\right)$. This reflects the red clay soil (Mũtune) sampled in Village1. Additional exploration of the relationship between texture and physicochemical properties identified as significantly different between best and worst fertility soil and the location was performed (Table 4-b). The GLM models included soil fertility evaluation and location as factors and it was found that there is significant difference between all properties identified and the texture categories. Multiple comparisons on the $95 \%$ confidence interval show significant difference in $\mathrm{pH}$, TOC and WFC among clayey, loamy and sandy texture. The respective values were higher for finer texture soils. The average values of AP, K and EC are higher for clayey, loamy and sandy respectively but the difference is not significant.

Table 4. Relationships between soil texture and (a) soil fertility evaluation or village location (Pearson chi-squared test) and (b) soil texture and the results of physicochemical analysis (multiple comparison) $(\mathrm{N}=116)$

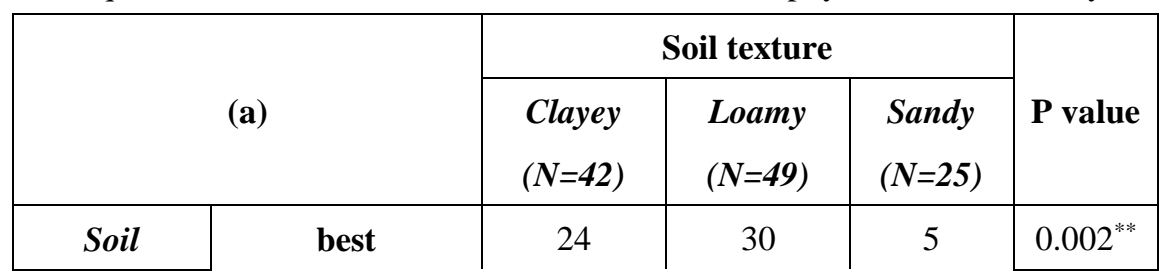




\begin{tabular}{|c|c|c|c|c|c|}
\hline $\begin{array}{c}\text { fertility } \\
\text { evaluation }\end{array}$ & worst & 18 & 19 & 20 & \\
\hline Village & $\mathbf{1}$ & 28 & 22 & 8 & $0.015^{*}$ \\
location & $\mathbf{2}$ & 14 & 27 & 17 & \\
\hline
\end{tabular}

455

\begin{tabular}{|c|c|c|c|c|}
\hline \multirow{2}{*}{ (b) } & \multicolumn{3}{|c|}{ Soil texture } & \multirow{2}{*}{$\begin{array}{c}P \\
\text { value }\end{array}$} \\
\hline & Clayey & Loamy & Sandy & \\
\hline$p H$ & $6.48^{\mathrm{a}}$ & $6.43^{\mathrm{a}}$ & $6.03^{\mathrm{b}}$ & \multirow{6}{*}{$\mathrm{P}<0.05$} \\
\hline TOC $\mathrm{g} \mathrm{kg}^{-1}$ & $1.21^{\mathrm{a}}$ & $0.99^{\mathrm{b}}$ & $0.97^{\mathrm{b}}$ & \\
\hline$A P m g k^{-1}$ & $76.0^{\mathrm{a}}$ & $76.1^{\mathrm{a}}$ & $64.20^{\mathrm{a}}$ & \\
\hline K cmol kg-1 & $1.23^{\mathrm{a}}$ & $1.09^{\mathrm{a}}$ & $1.03^{\mathrm{a}}$ & \\
\hline$E C d s / m$ & $0.09^{\mathrm{a}}$ & $0.08^{\mathrm{a}}$ & $0.07^{\mathrm{a}}$ & \\
\hline $\mathrm{WHC} \mathrm{gH}_{2} \mathrm{O}$ gdry soil ${ }^{-1}$ & $50.6^{\mathrm{a}}$ & $39.4^{\mathrm{b}}$ & $35.0^{\mathrm{c}}$ & \\
\hline
\end{tabular}

$* P<0.05, * * P<0.01$

Although Table 2 does not show a clear difference for colour with local soil classifications, farmers rely on colour as an indicator for their evaluation of soil fertility. Therefore, further correlation between colours from farmers' classification and the physicochemical data was performed (Table 5). From the 116 soil samples, 105 which could be categorized into the five major local soil types were selected and ordered into three categories: Blackish (n=36) including Ĩlimba and Mwiũ, Reddish (n=19) including Mũtune and No colour mentioned $(\mathrm{n}=50)$ including Nthangathĩ and Kĩvuthĩ. There was a significant difference of appearance for each colour soils in soil fertility evaluation $\left(\mathrm{P}=0.000^{* * *}\right)$ and between villages $\left(\mathrm{P}=0.017^{*}\right)$ using a chi-squared test (Table 5-a). Blackish and Reddish soils were mainly classified as best soil fertility locations and no colour soils were found in the worst soil fertile areas. There was more Blackish soil and less Reddish soil in Village2 than Village1. This reflects the sample of Mũtune from Village1 and Îlimba from Village2. Multiple comparisons on the $95 \%$ confidence interval show a significant difference for $\mathrm{pH}$, TOC, AP, EC and WHC among the Blackish, Reddish and No Colour soils. The average value of $\mathrm{K}$ is higher for Blackish, Reddish and No Colour respectively but the difference is not significant. The $\mathrm{pH}$, TOC and WHC can be associated with changes in both colour and texture; AP and EC were associated with local colour only.

Table 5. Relationship between local soil colour and (a) soil fertility evaluation or village (Pearson chi-squared test) (b) and results of the physicochemical analysis (multiple comparison) ( $\mathrm{N}=105)$

\begin{tabular}{|l|c|c|c|c|c|}
\hline \multirow{2}{*}{ (a) } & \multicolumn{2}{|c|}{ Colour of major local soil types } & \multirow{2}{*}{} \\
\cline { 3 - 5 } & $\begin{array}{c}\text { Blackish } \\
(\mathbf{N = 3 6})\end{array}$ & $\begin{array}{c}\text { Reddish } \\
(\mathbf{N = 1 9})\end{array}$ & $\begin{array}{c}\text { No Colour } \\
(\text { N=50 })\end{array}$ & \multirow{2}{*}{ P value } \\
\cline { 1 - 5 } Soil & best & 35 & 13 & 5 & 0.000 \\
\hline
\end{tabular}




\begin{tabular}{|l|c|c|c|c|c|}
\hline $\begin{array}{l}\text { fertility } \\
\text { evaluation }\end{array}$ & worst & 1 & 6 & 45 & \\
\hline Village & $\mathbf{1}$ & 12 & 14 & 23 & $0.017^{*}$ \\
\hline
\end{tabular}

476

\begin{tabular}{|c|c|c|c|c|}
\hline \multirow[b]{2}{*}{ (b) } & \multicolumn{3}{|c|}{ Colour of major local soil types } & \multirow{2}{*}{$\begin{array}{c}\mathbf{P} \\
\text { value }\end{array}$} \\
\hline & $\begin{array}{c}\text { Blackish } \\
(\mathrm{N}=36)\end{array}$ & $\begin{array}{c}\text { Reddish } \\
(\mathrm{N}=19)\end{array}$ & $\begin{array}{l}\text { No Colour } \\
\qquad(\mathbf{N}=\mathbf{5 0})\end{array}$ & \\
\hline$p H$ & $6.57^{\mathrm{a}}$ & $6.62^{\mathrm{a}}$ & $6.10^{\mathrm{b}}$ & \multirow{6}{*}{$\mathrm{P}<0.05$} \\
\hline TOC $\mathrm{g} \mathrm{kg}^{-1}$ & $1.05^{\mathrm{ab}}$ & $1.19^{\mathrm{a}}$ & $0.97^{b}$ & \\
\hline$A P m g k g^{-1}$ & $101^{\mathrm{a}}$ & $71^{\mathrm{ab}}$ & $54^{\mathrm{b}}$ & \\
\hline K cmol kg-1 & $1.24^{\mathrm{a}}$ & $1.09^{\mathrm{a}}$ & $1.07^{\mathrm{a}}$ & \\
\hline$E C d s / m^{I}$ & $0.10^{\mathrm{a}}$ & $0.07^{\mathrm{ab}}$ & $0.07^{b}$ & \\
\hline $\mathrm{WHC} \% \mathrm{gH}_{2} \mathrm{O}$ gdry soil $^{-1}$ & $47.8^{\mathrm{a}}$ & $44.1^{\mathrm{a}}$ & $37.8^{\mathrm{b}}$ & \\
\hline
\end{tabular}

$* P<0.05, * * P<0.01$

\section{Soil evaluation and historical narratives}

480 Farmers' narratives about their evaluation of soil fertility, classification and connection with social change were collected through focus group discussion with elder people and storytelling during individual interviews. In particular, farmers in both villages noted a change in local soil conditions compared with historical recollections were soils had become degraded, soil fertility had decreased and cultivation was more challenging: "For the past generation of farmers, there was a lot of humus, fertile soil...if working this humus, it reached until the knee. The soil was covered by humus so we couldn't see the soil type" (Village1); “All the soils were black (Mwiũ) so you didn't need to recognize 'soil type' in the past. The head of the family always decides the best place by checking if the soil is loose, if it can be dug by hand and if there is a lot of humus... but nowadays after two or three seasons in cultivation, the soil fertility is a problem and the crops do not grow well. When you then dig the soil, it will make a noise [from the stones] ... and this means is not a good field. In the past, the family could shift to other places as the land belonged to no one that time" (Village2). However, the introduction of regulation in land ownership impacted traditional land use systems and ultimate the quality of the soil as "after the surveyors came, they introduced new government rules and people were settled in the same place” (Village1 and 2) limiting farmers' ability to practice extensive agriculture or even long-term fallow rotation.

With limited capacity for many farmers to practice intensive farming and maintain soil fertility, there are challenges for current soil fertility: "The rain washes away the humus and top soils...after humus rich surface soil loss, other soils (Mũtune, Nthangathĩ, Kĩvuthĩ ) now appear" (Village1 and 2); "The population in the village has increased and people here often cut the trees to make charcoal to sell, so the forest is reduced" (Village1); "the soil colour was originally black but now it is a bit pale and this means 
the soil has become old. My crop production has been reduced" (Village2). Individual storytelling revealed that some farmers actively were attempting to practice low-cost improvement techniques through organic manures, soil and water conservation or mulching: "when I moved to the place and built the new house, the soil was poor... but I collected leaves and humus from the forest and spread it over the field and it has made the soils more fertile" (Village1).

\section{Discussion}

Having revealed the similarities between the characteristics used by farmers to evaluate best and worst soil fertility and the physicochemical analysis, this section reflects on why farmers understand the soil in the way they do. In particular, the reasons why farmers relied on texture and colour as their main indicators of soil fertility are explored. The factors that shape farmers' understanding include holistic information of farming experiences, historical social and environmental narratives, a detailed knowledge of the landscape and spatial scale.

Both local soil classification and evaluation of soil fertility in Kitui was dominated by soil texture and colour. The two is also main indicators in other local soil taxonomy (Barrera-Bassols and Zinck, 2003; Osbahr and Allan, 2003) and fertility evaluation (Murage et al., 2000; Mairura et al., 2007), and global soil classification(IUSS Working Group WRB, 2015). Kitui farmers used other fertility indicators including crop performance, roots growth, management effects, and workability which were observed and evaluated in their daily experience, through family and community knowledge, and from awareness of local field information (Ingram et al., 2018). The appearance of macro-fauna or indicator plant species which mention in other studies (Murage et al., 2000; Mairura et al., 2007) were not answered from interviewees voluntarily in this study. It would be due to rare to see organisms on fields and less attention for weeds species than other indicators in the study area.

This simple approach to soil classification and evaluation may reflect the relatively short history of agriculture in this area. According to farmers' narratives of agricultural development in the region, soil knowledge and management has been shaped by social change. Traditionally farmers have evaluated the soil humus and texture to decide on the best locations for shifting cultivation since the $17^{\text {th }}$ Century. These two indicators were also reported as common in indigenous soil classification in other areas (Barrera-Bassols and Zinck, 2003). However, these evaluations may not have been relied upon as much in the past because there was plentiful fertile land before $19^{\text {th }}$ century. Increased settlement and the implementation of a land ownership system in the 1970's (Ikeno, 1989) restricted local farmers' traditional systems, with losses in the humus rich surface soil and soil erosion of some sub-soils. It is this reworked soil that is captured in the current local soil classification, but which may have been used for less than half a century. While nearby Machakos, another Kamba settlement, suffered degradation of its agricultural land 
539 (Karanja et al 2017, Tiffen et al. 1994). The story of agricultural extension in Kitui is however later than 540 Machakos and there have been no large-scale land conservation project as within Machakos (Karanja et al 541 2017, Ikeno 1989, personal communication with Extension Officers in Kitui). Investment in terracing of 542 fields has been ad hoc in Kitui and many have been damaged by high intensity rain. The growing population has placed pressure on forest resources, reduced farm sizes through traditional subdivision of land holdings for each generation, increased local food demand and required a more intensive farming approach (Ikeno, 1989). The narratives and soil knowledge reported by farmers in the study primarily reflects their experience after this period of social change.

Nevertheless, farmers construct a detailed local knowledge of their soils within their own farm, capturing small scale variation and a sense of connection with the history of their soil. Their local soil classifications focus on this small spatial scale, which is relevant to day-to-day farming decisions. This scalar dimension has been observed in other studies, in Niger (Osbahr and Allan, 2003) and in Rwanda (Rushemuka et al., 2014). Location and connectedness with the landscape also shapes local soil evaluations. Land near to the family homestead or the river were seen as having the most fertile soil due to the availability of nutrients and water. The homestead benefits from organic waste, livestock and waste water (Woomer et al., 1998) while the river supplies water and nutrients from deposited sediments. The type of sediments is decided by topography, with sand in the middle of the river while relatively flat sections allow clay with nutrients to accumulate (Brady and Weil, 2016). These areas are locally seen as demonstrating improved soils without labour input and classified as the best soil. Farmers are often more likely to focus further agricultural input in the most productive areas of their farm (Murage et al., 2000).

There were differences in how farmers recognised soils between the two study villages. For example, while farmers in Village1 classified some soils on their farm in English, this was not the case in Village2. This reflected the availability of agricultural information in the school and access to an agricultural extension worker in Village1. There was difficulty in communication between extension workers and farmers in Village2 which was in a comparatively more remote area (Anderson, 2006). The positive effects of extension services in adding soil science-based knowledge to farmers is well known (Muyanga and Jayne, 2006). Extension staffs had informed farmers that "Sandy loam soil was the best for cultivation of maize" (personal communication with Extension Officers in Kitui), although a local term which meant "loam" did not exist in this area and farmers explained a loam texture as mixture of clay and sand. Another difference between the two villages was the selection of the location determined as the best or worst soil fertility. This can be attributed to a difference in availability of land. As illustrated by the number of farmers who have more than two fields (Village2 is higher), land is more difficult to acquire, buy or rent in Village1 because of a higher population density in the area since it is nearer to the town (The County Government of Kitui, 2014). Moreover, the elevation of Village1 is similar but bit higher than Village2 and the availability of black clay soil near river which made by alluviums is less than Village2. Farmers in Village1 have limited opportunity to use away-fields and consider differences in soil fertility on their 
owned fields as an effect resulting from better inputs and management than natural variation in soil type. As mentioned above, application of organic matter from house change the soil colour darker and increase black soils in local classification. While both intensification and natural diversity can lead to differences in texture and colour, the core concepts used by farmers for their evaluation of soil in both locations was the same. Given national interest in supporting intensification of these soils, understanding the underlying epistemological framings for management decisions by farmers are vital (Bozzola, Smale and Falco, 2016; Verkaart et al., 2017).

Furthermore, there was consistency in aspects of the core concepts (figure 1) used to evaluate soil fertility by scientists using soil science methods and farmers local knowledge in Kitui. The results of the physicochemical analysis from locations identified by farmers as the best soil fertility areas were significantly better than those identified as the worst, and in particular this reflected a focus on organic matter content, pH, AP, K and WFC. This finding supports the argument by Murage et al. (2000) and Mairura et al. (2007) that Kenyan farmers' soil evaluation is highly consistent with soil science evaluations. Texture is the basis by which to understand soil structure and it is related to aeration, space for plant roots and moisture, which directly affect crop performance (Brady and Weil, 2016). Thus soil texture can indicate the potential level of nutrient and water holding capacity of a soil (Brady and Weil, 2016), which was identified to be significantly different in $\mathrm{pH}$, TOC and WHC (Table 4) between the soils with different texture. coarse soils were determined by farmers to be problematic and often identified as the worst soil fertility location on their farm. This reflected their understanding of soil process, such as rapid drainage of water through the coarse soil particles, a problem in a region that experiences erratic rains and frequent drought spells because it leads to crop loss. Even if these are low-cost water conservation techniques, they can be labour intensive (Oguge and Oremo, 2018). The coarse particles are due to components from the metamorphic bedrock (Bishop, Woolley and Hamilton, 1999), especially silicate minerals such as microcline and oligoclase (Mine \& Geological Department Kenya colony North-West Quadrant, 1954) which create sand. These sandy soils are considered problematic for farming locally and are called Yalata in KiKamba. Other studies have described coarse textured soils to be perceived as problematic by farmers (e.g. the Tanah Tahinagan soils in Indonesia) (Kamidohzono et al. 2002).

The colour of a soil is however often considered the most remarkable visual feature and can indicate a range of soil properties and processes. For example, there is a known correlation between a dark coloured soil and the amount of organic matter (Brady and Weil, 2016). In this study, significant differences were shown to be between local coloured soils and 'no colour' soils for pH, TOC, AP, EC and WHC. However, there was no significant difference between blackish and reddish soil. This reflects generally low organic matter content in the soils around Kitui, a problem which has been exacerbated by surface soil loss. Therefore, the relationship between darker soil and organic matter content is not clearly shown in this study. The colour of the soil can be explained by the clay types in this area. The source of the black colour clay described as Mwiũ or Ĩlimba was alluvial deposits, while the red clay of Mũtune came from the local 
615 iron-rich metamorphic rock (personal communication, Professor in Soil Formation, University of Nairobi).

616 It can be concluded that farmers first evaluate their soils by texture, and second, they classify by the colour.

617 Although soil colour in local classification is not clearly divided in Munsell colour chart but the space for

618 further research of local colour epistemology is remaining as precise recognition of animal coat-colour

619 among the Bodi in Ethiopia (Fukui, 1996).

620

621 Summarizing the achievements of this study as adapted in Figure 1 (Barrios et al., 2006), Kitui farmers

622 and soil science shares the use of soil texture and colour for soil fertility evaluation as core concepts. The

623 information from farmers' observation and evaluation of field managements and history of social and

624 environmental changes is lacking in soil science. On the other hand, the relationships between soil

625 properties and soil process is less well understood by farmers, and the importance of organic matter is not

626 mentioned by farmers at all, although it is dominant topic for water retention by soil scientists (Yageta $e t$

627 al., no date; Brady and Weil, 2016). Water availability is a particularly challenging factor for agricultural

628 production in Kitui and most farmers rely on rainfed supply, exposing them to the risk of drought (Ikeno,

629 1989). Instead of holistic (ref), Kitui farmers currently use qualitative indicators more readily than

630 quantitative measures. Using soil colour and texture as an entry point and sharing of information about soil

631 processes (or "know-why") about water and nutrient retention together with farmers empirical knowledge

632 could help to provide a genuine two-way form of communication and social learning (Leeuwis and Aarts,

633 2011; Lie and Servaes, 2015). The creation of local tailor-made soil assessment systems using hybrid

634 knowledge can integrate precise spatial information from farmers and the mechanisms of soil function

635 from soil science, which would then provide the potential to support effective precision agriculture system

636 (Osbahr and Allan, 2003) and increase sustainability and adaptability of soil management technology.

The results presented in this paper demonstrate that there is a epistemological question of the difference of

640 soil colour and texture classification between farmers and soil science. Further work to explore the

641 relationship around this in different locations, the differences among farmers, and to develop a deeper

642 understanding of local understanding of the relationship between indicators and key soil processes in these

643 different context would be useful. Although this study adopted a case study approach and results include

644 site-specific data, the methods captured the main dimensions about farmers' perception of soil fertility and

645 the similarity and dissonances with soil science knowledge - this illustrates how the impacts of location

646 and historical narratives as social context shape soil knowledge beyond just a collection of local soil

647 taxonomy (Niemeijer and Mazzucato, 2003).

648

649

650

5. Conclusion

651

652 Farmers in Kitui used a soil classification system based on local knowledge and evaluation processes of 
structure and function to assess soil fertility. The factors that shape farmers' understanding include holistic information of farming experiences with observation and evaluation, historical social and environmental narratives, a detailed knowledge of the landscape and spatial scale. Local historical narratives reveal the importance in changes to humus, consistent with technical knowledge about the role of soil organic matter for soil fertility. The main indicators used in evaluation of good soil fertility are texture and colour, while texture alone is used for poor soil fertility. This paper provides better understanding of farmer soil classification that help to inform scientists working with alternative frameworks, sharing the importance of soil colour and texture with farmers, providing the information of "know-why" and learn the importance of location from farmers. The two-way communication could create the hybrid knowledge which become a base for the development of integrated soil management approaches. Further research could investigate if systems of local soil colour classification and the role of local historical narratives is different in other contexts, as well as differences of understanding among farmers and the relationship between indicators and key soil processes. This paper has presented a straightforward approach for comparing qualitative and quantitative knowledge and the method could be used by extension workers in other locations.

\section{Acknowledgements}

The authors acknowledge the affiliation with Dr. Robert Mbeche and the Department of Agriculture \& Resources Economics in Jomo Kenyatta University of Agriculture and Technology, the soil chemical analysis by the soil laboratory in Nairobi University, Academic support for the data collection in Kitui County by Dr. Patrick M Maundu, the National Museums of Kenya, and the financial support from the Konosuke Matsushita Memorial Foundation to Yoshie Yageta for the fieldwork.

\section{References}

Agrawal, A. (1995) 'Dismantling the divide between indigenous and scientific knowledge', Development and Change, 26(3), pp. 413-439. doi: 10.1111/j.1467-7660.1995.tb00560.x.

Anderson, J. (2006) 'The rise and fall of training and visit extension: an Asian mini-drama with an African epilogue', Vasa, (May), pp. 1-30. doi: 10.1596/1813-9450-3928.

Andrew, F. and Salvadori, C. (1979) Peoples and Cultures of Kenya. Nairobi: Transafrica.

Ashman, M. and Puri, G. (2008) Essential soil science: a clear and concise introduction to soil science. Hoboken: Wiley.

Bado, V. B. and Bationo, A. (2018) 'Integrated Management of Soil Fertility and Land Resources in Sub-Saharan Africa: Involving Local Communities', Advances in Agronomy, In Press.

Barrera-Bassols, N. and Zinck, J. A. (2003) 'Ethnopedology: a worldwide view on the soil knowledge of local people', Geoderma, 111(3-4), pp. 171-195. doi: 10.1016/S0016-7061(02)00263-X.

\section{Barrios, E. I. of soil quality: A. S. development of a methodological guide for linking local and technical} knowledge et al. (2006) 'Indicators of soil quality: A South-South development of a methodological guide for 
linking local and technical knowledge', Geoderma, 135, pp. 248-259. doi: 10.1016/j.geoderma.2005.12.007.

Barrios, E. and Trejo, M. T. (2003) 'Implications of local soil knowledge for integrated soil management in Latin America', Geoderma, 111(3-4), pp. 217-231. doi: 10.1016/S0016-7061(02)00265-3.

Berazneva, J. et al. (2018) 'Empirical assessment of subjective and objective soil fertility metrics in east Africa: Implications for researchers and policy makers', World Development, 105, pp. 367-382. doi: 10.1016/j.worlddev.2017.12.009.

Bishop, A. C., Woolley, A. R. and Hamilton, W. R. (1999) Philip's Minerals, Rocks \& Fossils. London: Octopus publishing group.

Black, A. W. (2000) 'Extension theory and practice: a review', Australian Journal of Experimental Agriculture, 40(4), pp. 493-502. Available at: http://www.publish.csiro.au/?paper=EA99083 (Accessed: 13 November 2014). Bozzola, M., Smale, M. and Falco, S. Di (2016) 'Climate, Shocks, Weather and Maize Intensification Decisions in Rural Kenya', in AAEA Annual Meeting. Boston, pp. 123-144.

Brady, N. and Weil, R. (2016) The nature and properties of soils. 15th edn. London: Pearson Education. Available at: http://www.cabdirect.org/abstracts/19961906536.html (Accessed: 1 June 2015).

Brokensha, D., Warren, D. and Werner, O. (1980) Indigenous knowledge systems and development. University Press of America. Available at: http://www.cabdirect.org/abstracts/19811877204.html (Accessed: 13 November 2014).

Carter, M. R. and Gregorich, E. G. (2008) Soil sampling and methods of analysis. Edited by Canadian Society of Soil Science. Boca Raton: CRC Press.

Coffey, A. and Atkinson, P. (1996) Making sense of qualitative data: complementary research strategies. Thousand Oaks: Sage Publications. Available https://uk.sagepub.com/en-gb/eur/making-sense-of-qualitative-data/book5617 (Accessed: 1 May 2018).

Cook, S., Adams, M. and Corner, R. (1998) 'On-farm experiments to determine site-specific response to variable inputs', in Fourth International Conference on Precision Agriculture. St. Paul, Minnesota: ASA/CSSA/SSSA, ASPRS, PPI. Available at: https://scholar.google.com/scholar?hl=ja\&q=cook+1998+on-farm\&btnG=\&lr=lang_en\%7Clang_ja (Accessed: 17 March 2017).

County Government of Kitui (2013) County Integrated Development Plan (CIDP) 2013-2017. County Government of Kitui (2014) Annual Development Plan 2014/15. Kitui, Kenya.

Duvall, C. S. (2008) 'Classifying physical geographic features: The case of Maninka farmers in Southwestern Mali', Geografiska Annaler: Series B, Human Geography, 90(4), pp. 327-348. doi: 10.1111/j.1468-0467.2008.00297.x.

Fukui, K. (1996) 'Co-evolution between humans and domesticates: the cultural selection of animal coat-colour diversity among the Bodi', in Ellen, R. F. and Fukui, K. (eds) Redefining Nature: Ecology, Culture, and Domestication. Oxford: Berg, pp. 319-386.

Guzman, C. D. et al. (2018) 'Developing Soil Conservation Strategies with Technical and Community Knowledge in a Degrading Sub-Humid Mountainous Landscape', Land Degradation and Development, 29(3), pp. 749-764. doi: 10.1002/ldr.2733. 
Ikeno, J. (1989) Ukanbani: tōbu Kenia no shōnō Keiei. Chiba: Ajia Keizai Kenkyūjo. Available at: https://www.google.co.uk/search?q=ukanbani\&ie=utf-8\&oe=utf-8\&client=firefox-b\&gfe_rd=cr\&ei=b2f_WOX ANs_W8gflqJXgCQ (Accessed: 26 April 2017). Ingram, J. (2008) 'Are farmers in England equipped to meet the knowledge challenge of sustainable soil management? An analysis of farmer and advisor views', Journal of environmental management, 86(1), pp. 214228. Available at: http://www.sciencedirect.com/science/article/pii/S0301479706004300 (Accessed: 27 October 2014). Ingram, J. et al. (2018) 'Reconceptualising translation in agricultural innovation: A co-translation approach to bring research knowledge and practice closer together', Land Use Policy. Elsevier, 70(May 2017), pp. 38-51. doi: 10.1016/j.landusepol.2017.10.013. Ingram, J., Fry, P. and Mathieu, A. (2010) 'Revealing different understandings of soil held by scientists and farmers in the context of soil protection and management', Land Use Policy, 27(1), pp. 51-60. doi: 10.1016/j.landusepol.2008.07.005. Irzik, G. (1998) 'Philosophy of science and radical intellectual Islam in Turkey', in W.W., C. (ed.) Socio-Cultural Perspectives on Science Education. Science \& Technology Education Library, vol 4. Dordrecht: Springer. Available at: http://link.springer.com/chapter/10.1007/978-94-011-5224-2_9 (Accessed: 17 February 2015).

746 IUSS Working Group WRB (2015) World Reference Base for Soil Resources 2014, update 2015 International soil classification system for naming soils and creating legends for soil maps, World Soil Resources Reports No 106.

Rome:

FAO.

Available

at:

749 https://scholar.google.co.jp/scholar?hl=ja\&q=World+reference+base+for+soil+resources.\&btnG=\&lr=\#2

750 (Accessed: 1 June 2015).

751 Jones, U. S. (1982) Fertilizers and soil fertility. 2nd edn. Reston: Reston Pub. Co.

752 Kamidohzono, A. et al. (2002) 'Indigenous soil fertility evaluations in Sipisang Village of Minangkabau people, 753 West Sumatra', Japanese Journal of Soil Science and Plant Nutrition, 73, pp. 741-753. Available at: 754 http://agris.fao.org/agris-search/search.do?recordID=JP2003002412 (Accessed: 6 October 2014).

755 Karanja, E. et al. (2017) 'Supporting Farmer Innovation to Enhance Resilience in the Face of Climate Change in 756 Farming Systems in Machakos and Kitui Counties, Kenya', in Climate Change Adaptation in Africa. Cham: 757 Springer International Publishing, pp. 677-688. doi: 10.1007/978-3-319-49520-0.

758 Keeney, D. and Nelson, D. (1982) 'Nitrogen-Inorganic Forms', in Page, A. L. (ed.) Methods of Soil Analysis, 759 Part 2-Chemical and Microbiological Properties, Agronomy Monograph 9. 2nd edn. Madison: ASA-SSSA.

761 https://dl.sciencesocieties.org/publications/books/abstracts/agronomymonogra/methodsofsoilan2/643 (Accessed: 7622 December 2016).

763 KICABA Cultural Center (2013) The county, About Kitui, Visitkitui. Available at: 764 http://www.visitkitui.com/about-kitui/county (Accessed: 5 May 2018).

765 Landon, J. R. (1984) Booker tropical soil manual : a handbook for soil survey and agricultural land evaluation 766 in the tropics and subtropics. London: Booker Agriculture International Ltd. 
Lavkulich, L. M. (1981) Methods manual: Pedology laboratory. Vancouver: Department of Soil. Science.

768 University of British Columbia.

769 Leeuwis, C. and Aarts, N. (2011) 'Rethinking Communication in Innovation Processes: Creating Space for 770 Change in Complex Systems', The Journal of Agricultural Education and Extension, 17(1), pp. 21-36. doi: 10.1080/1389224X.2011.536344. Lie, R. and Servaes, J. (2015) 'Disciplines in the Field of Communication for Development and Social Change', Communication Theory, 25, pp. 244-258. Mairura, F. S. et al. (2007) 'Integrating scientific and farmers' evaluation of soil quality indicators in Central Kenya', Geoderma, 139(1-2), pp. 134-143. doi: 10.1016/j.geoderma.2007.01.019. Mehlich, A. (1953) 'Determination of P, Ca, Mg, K, Na, and NH4', in North Carolina Soil Test Division (Mimeo 1953) S.T.D.P. No. 1-53, pp. 23-89. Available at: http://www.ncagr.gov/AGRONOMI/pdffiles/mehlich53.pdf (Accessed: 2 December 2016). Mine \& Geological Department Kenya colony North-West Quadrant (1954) 'Geological map of the Kitui area'. Murage, E. W. et al. (2000) 'Diagnostic indicators of soil quality in productive and non-productive smallholders' fields of Kenya's Central Highlands', Agriculture, Ecosystems \& Environment, 79(1), pp. 1-8. doi: 10.1016/S0167-8809(99)00142-5.

Muyanga, M. and Jayne, T. (2006) 'Agricultural extension in Kenya: Practice and policy lessons', Working paper, 26. Available at: http://www.oerafrica.org/FTPFolder/Agshare/Agribusiness/resources/Module 1/M1L3/Agricultural Extension Paper 2006.pdf (Accessed: 9 February 2015). NAAIAP (2014) Soil suitability evaluation for maize production in Kenya. Available at: http://kenya.soilhealthconsortia.org/?wpfb_dl=3 (Accessed: 7 April 2017).

788 Nelson, W. L., Mehlich, A. and Winters, E. (1953) 'The development, evaluation, and use of soil tests for phosphorus availability', Agronomy, 4(2), pp. 153-188. Available at:

$790 \mathrm{https}: / /$ scholar.google.com/scholar?q=The+development $\% 2 \mathrm{C}+$ evaluation $\% 2 \mathrm{C}+$ and+use++of + soil+tests+for+ph 791 osphorus+availability\&btnG=\&hl=ja\&lr=lang_en\%7Clang_ja\&as_sdt=0\%2C5.

792 Niemeijer, D. and Mazzucato, V. (2003) 'Moving beyond indigenous soil taxonomies: local theories of soils for 793 sustainable development', Geoderma, 111(3-4), pp. 403-424. doi: 10.1016/S0016-7061(02)00274-4.

794 Oguge, N. and Oremo, F. (2018) 'Fostering the Use of Rainwater for Off-Season Small-Scale Irrigation in Arid 795 and Semi-arid Areas of Kenya', in Rainwater-Smart Agriculture in Arid and Semi-Arid Areas. Cham: Springer, pp. 159-174. doi: 10.1007/978-3-319-66239-8_9.

797 Okalebo, J. R. et al. (1993) Laboratory methods of soil and plant analysis : a working manual. Nairobi: Tropical 798 Soil Biology and Fertility Programme.

799 Osbahr, H. and Allan, C. (2003) 'Indigenous knowledge of soil fertility management in southwest Niger', 800 Geoderma, 111(3-4), pp. 457-479. doi: 10.1016/S0016-7061(02)00277-X.

801 Ralph, J. et al. (2006) Farm management handbool of Kenya: Part C East Kenya. 2nd edn. Nairobi: Ministry of 802 Agriculture, Kenya.

803 Republic of Kenya (2014) Economic Survey 2014.

804 Richards, L. (1954) 'Agriculture handbook no. 60', US Department of Agriculture, USA. 
Richelle, L. et al. (2018) 'Looking for a dialogue between farmers and scientific soil knowledge: Learnings from an ethno-geomorphopedological study in a Philippine's upland village', Agroecology and Sustainable Food Systems. Taylor \& Francis, 42(1), pp. 2-27. doi: 10.1080/21683565.2017.1322661.

808 Robson, C. (2011) Real world research : a resource for users of social research methods in applied settings. 3rd 809 edn. Hoboken: Wiley.

810 Rocheleau, D. (1988) 'The user perspective and the agroforestry research and action agenda', in Henry L. Gholz 811 (ed.) Agroforestry: realities, possibilities, and potentials. Cham: Springer. Available at: 812 https://scholar.google.co.jp/scholar?q=The+user+perspective+and+the+agroforestry+research+and+action+agen 813 da\&btnG=\&hl=ja\&lr=lang_en\%7Clang_ja\&as_sdt=0\%2C5 (Accessed: 16 March 2017).

814 Roland, B., Rubens, A. and Azupogo, H. A. (2018) 'Combining indigenous wisdom and academic knowledge to 815 build sustainable future : An example from rural Africa', 10(February), pp. 8-18. doi: 10.5897/JASD2017.0481. 816 Rushemuka, N. P. et al. (2014) 'Farmers' soil knowledge for effective participatory integrated watershed 817 management in Rwanda: Toward soil-specific fertility management and farmers' judgmental fertilizer use', 818 Agriculture, Ecosystems \& Environment, 183, pp. 145-159. doi: 10.1016/j.agee.2013.10.020.

819 Scott, C. and Walter, M. (1993) 'Local knowledge and conventional soil science approaches to erosional 820 processes in the Shivalik Himalaya', Mountain Research and Development, 13(1), pp. 61-72. Available at: http://www.jstor.org/stable/3673644 (Accessed: 8 October 2014).

822 Soil Survey Division Staff (2017) Soil survey manual. Edited by C. Ditzler, K. Scheffe, and H. C. Monger.

823 Washington, D.C.: Government Printing Office (USDA Handbook 18). Available at: 824 https://www.nrcs.usda.gov/wps/portal/nrcs/detailfull/soils/ref/?cid=nrcs142p2_054262 (Accessed: 7 April 825 2017).

826 Sombroek, W. G., Braun, H. M. H. and Pouw, B. J. A. van der (1980) Exploratory soil map, scale 1:1,000,000, 827 Exploratory Soil Survey Report No. E1.

828 The County Government of Kitui (2014) Kitui County Villages Bill, 2014. Available at: 829 http://www.kitui.go.ke/images/downloads/Kitui_County_Villages_Bill_2014_Bill.pdf (Accessed: 29 November 830 2016).

831 Thien, S. J. (1979) 'A flow diagram for teaching texture by feel analysis', Journal of Agronomic Education, 8(2), pp.

$54-55$.

Available

at:

833 https://scholar.google.com/scholar?hl=ja\&q=A+flow+diagram+for+teaching+texture+by+feel+analysis\&btnG= 834 \&lr=lang_en\%7Clang_ja.

835 Tiffen, M., Mortimore, M. and Gichuki, F. (1994) More people less erosion: environmental recovery in Kenya. 836 Hoboken: Wiley. Available at: http://www.popline.org/node/303096 (Accessed: 28 April 2017).

837 Tongco, M. D. C. (2007) 'Purposive sampling as a tool for informant selection', Ethnobotany Research and 838 Applications, 5, pp. 147-158.

839 Vanclay, F. and Lawrence, G. (1995) The environmental imperative: eco-social concerns for Australian 840 agriculture. Rockhampton: Central Queensland University Press. Available at:

841 http://acquire.cqu.edu.au:8080/vital/access/manager/Repository/cqu:8884?sort=type\%5C （Accessed: 14 842 November 2014). 
Verkaart, S. et al. (2017) 'Intensify or diversify? Agriculture as a pathway from poverty in eastern Kenya', ICRISAT - Socioeconomics Discussion Paper Series, 40(40), pp. 1-25.

845 Vilenskii, D. G. (1957) Soil science. 3rd enlarg. Moscow: State Teacher's College Publishing House.

846 Walker, D. H., Sinclair, E. L. and Thapa, B. (1995) 'Incorporation of indigenous knowledge and perspectives in 847 agroforestry development Part 1 : Review of methods and their application', Agroforestry Systems, 30(1), pp. $848 \quad 235-248$.

849 Walkley, A. (1947) 'A critical examination for a rapid method for determining organic carbon in soils: effect of 850 variations in digestion conditions and of inorganic soil constituents', Soil Science, 63(4), pp. 251-264. Available 851 at:

852 http://journals.lww.com/soilsci/Citation/1947/04000/A_CRITICAL_EXAMINATION_OF_A_RAPID_METHO 853 D_FOR.1.aspx.

854 Wambugu, S. K., Karugia, J. T. and Oluoch-Kosura, W. (2011) 'Conditions for Achieving Sustained Agricultural 855 Insentification in Africa: Evidence from Kenya', in Djurfeldth, G., Aryeetey, E., and Isinika, A. C. (eds) African 856 Small holders, Food crops, markets and policy. UK: CABI, pp. 214-236.

857 WFP (2007) National roadnetwork. Available at: http://192.156.137.110/gis/search.asp?id=337 (Accessed: 5 858 May 2018).

859 Whiteley, W. H. and Muli, M. G. (1962) Practical introduction to Kamba. Oxford: Oxford University Press.

860 Available at:

861 https://www.google.com/search?q=Practical+introduction+to+Kamba\&ie=utf-8\&oe=utf-8\&client=firefox-b

862 (Accessed: 18 May 2018).

863 Wilbanks, T. J. and Kates, R. W. (1999) 'Global Change in Local Places: How Scale Matters', Climatic Change. 864 Kluwer Academic Publishers, 43(3), pp. 601-628. doi: 10.1023/A:1005418924748.

865 Wild, A. (2003) Soils, land, and food: managing the land during the twenty-first century. Cambridge: 866 Cambridge University Press.

867 Woomer, P. et al. (1998) 'Agricultural resource management by smallhold farmers in East Africa', Nature and 868 Resources, 34(4), pp. 22-33. Available at: 869 http://scholar.google.co.jp/scholar?q=woomer+agricultural+resource\&btnG=\&hl=ja\&as_sdt=0,5\#0 (Accessed: 8707 December 2014).

871 Yaalon, D. H. and Berkowicz, S. (1997) History of soil science - international perspectives., Advances in 872 geoecology. Reiski: Catena Verlag. Available at: http://www.cabdirect.org/abstracts/19971910951.html 873 (Accessed: 8 October 2014).

874 Yageta, Y. et al. (no date) 'Recognising the role of different knowledges in soil fertility management: synergies 875 between mental models from farming and science', Soil Use and Management.

876 Yin, R. (2013) Case study research: Design and methods. 5th edn. California, London, Sage: Thousand Oaks.

877 Available at:

878 https://books.google.co.jp/books?hl=ja\&lr=lang_ja\%7Clang_en\&id=OgyqBAAAQBAJ\&oi=fnd\&pg=PT243\&d

879 q=Case+Study+Research:+Design+and+Methods\&ots=FbF4o8q53j\&sig=WEbCaZW5MWeBq9gOhrHxNOKY

880 QKk (Accessed: 24 January 2018). 
